\title{
Prediction of genetic gains through selection of sweet potato accessions
}

\author{
Pablo F Vargas ${ }^{1} \mathbb{D}$; Maria Eduarda F Otoboni ${ }^{2} \mathbb{D}$; Beatriz G Lopes ${ }^{3 \mathbb{D}}$; Bruno E Pavan ${ }^{2 \mathbb{D}}$
}

${ }^{1}$ Universidade Estadual Paulista (UNESP), Registro-SP, Brasil; pablo.vargas@unesp.br; ${ }^{2}$ Universidade Estadual Paulista (UNESP), Ilha Solteira-SP, Brasil; eduarda.otoboni@unesp.br; be.pavan@unesp.br; ${ }^{3}$ Universidade de São Paulo (USP), Piracicaba-SP, Brasil; beatrizgl@ usp.br

\begin{abstract}
Due to the high genetic variability found in sweet potato and a low number of cultivars available on the market, there are opportunities for necessary improvements in crop breeding programs. The selection indexes are a favorable strategy to achieve higher yields through genetic gains obtained with the future population. Thus, the objective was to evaluate the selection gain of agronomic characters from sweet potato accessions for root production and dual-aptitude. 95 accessions and two commercial cultivars (Braslandia Branca and Brazlândia Roxa) were evaluated. A randomized block design with three replications of ten plants per plot was used. The index proposed by Mulamba \& Mock was used to select superior individuals. The evaluated population showed high genetic variability providing considerable selection gains, being recommended some clones for tests of value for cultivation and use. The VR13-61 accession was the most recommended for root production and VR13-11 and VR13-22 for dual-aptitude.
\end{abstract}

Keywords: Ipomoea batatas, plant breeding, genetic variability.

\begin{abstract}
RESUMO
Predição de ganhos genéticos com a seleção em acessos de batata-doce

Devido à alta variabilidade genética encontrada na cultura da batata-doce e às poucas cultivares disponíveis no mercado, são identificadas oportunidades de melhorias necessárias nos programas de melhoramento genético da cultura. Diante disso, o uso do índice de seleção torna-se uma estratégia favorável para que sejam alcançadas melhores produtividades por meio dos ganhos genéticos obtidos com a população futura. Desta forma, objetivou-se avaliar o ganho de seleção de caracteres agronômicos de acessos de batata-doce para produção de raiz e dupla aptidão (produtivos em raiz e parte aérea). Foram avaliados 95 acessos e duas cultivares comerciais (Brazlândia Branca e Brazlândia Roxa). Utilizou-se delineamento em blocos casualizados com três repetições de dez plantas por parcela. Foi empregado o índice proposto por Mulamba \& Mock para a seleção de indivíduos superiores. A população avaliada apresentou alta variabilidade genética proporcionando ganhos consideráveis com a seleção, sendo recomendados alguns clones para ensaios de valor de cultivo e uso. O acesso VR13-61 foi o mais recomendado para produção de raiz e VR13-11 e VR13-22 para dupla aptidão.
\end{abstract}

Palavras-chave: Ipomoea batatas, melhoramento genético de plantas, variabilidade genética.

Received on April 21, 2020; accepted on September 18, 2020

$\mathrm{T}$ The sweet potato (Ipomoea batatas) is a tuberous vegetable belonging to the Convolvulaceae family and represents great socioeconomic importance due to its high nutritional value, in addition to demonstrating rusticity in the cultivation, considerable capacity for energy production in a short time, and wide climatic adaptation (Silva et al., 2015).

Great genetic diversity is observed among the various sweet potato cropping regions, which can be explained due to the frequent plant introductions of this species from places far from its origin center (Azevedo et al., 2015). Due to the broad phenotypic and genotypic variability of the crop, there exist the possibility to select materials for various purposes, such as obtaining materials resistant to pests and diseases, providing better nutritional quality, higher dry matter content, and increased production of haulms for the animal nutrition (Monteiro et al., 2007). In addition, there are dual-purpose genotypes, i.e. they perform excellent production both for tuberous roots, intended for home consumption, and haulms, suited for animal feeding.

Despite being a worldwide important crop, the level of technology applied by most growers is much lower than desirable, especially when it comes to the development of new productive cultivars that are adaptable to different growing regions (Massaroto et al., 2014). Thus, there are no varieties recommended for specific cultivation in each region (Cavalcante et al., 2009). Low sweet potato yields in Brazil are commonly reported even though the crop presents high productive potential, mainly due to the adoption of outdated genotypes (Marchese et al., 2010).

For breeding programs, biometric analyzes are decisive in the choice of methods to be used, mainly estimates 
of genetic parameters such as genotypic variance, heritability, genetic variation coefficient, and variation index, thus allowing to perform inferences on selection gains prediction (Azevedo et al., 2015).

The selection indexes (SI) for several characters provide the achievement of more adapted and productive genotypes through the gathering of several favorable attributes. Selection based on just a single characteristic is not appropriate, as even if it leads to a superior final individual in relation to this characteristic, it can result in unsatisfactory performances for the other traits of interest (Cruz et al., 2004). In this sense, the index adopted must enable the correct classification of the genotypes, considering, simultaneously, the different characters (Krause et al., 2012).

The SI represents a reliable alternative to breeding programs that aim at percentage genetic gains. They are responsible for genotypes superiority or inferiority in all the simultaneous traits. The gene frequency of favorable alleles in characters of interest can be gradually improved with the use of suitable selection methods. In this sense, because sweet potatoes have wide genotypic and phenotypic variability, in addition to being a crop that has not been studied genetically, there are numerous opportunities to obtain new cultivars through the selection of superior genotypes. Thus, the use of SI can be considered an efficient methodology for sweet potato crop, aiming to identify populations and individuals with better genotypic values, allowing the comparison of cultivars available on the market with promising accessions and genotypes.

Among the various existing indexes, Mulamba \& Mock (1978) proposed an index based on the sum of ranks, which aims to classify the genotypes as to each of the characteristics according to the order favorable to improvement (Freitas Júnior et al., 2009).

Given the above, the objective was to evaluate the gain in the selection of agronomic characters from sweet potato accessions for root production and dualpurpose.

\section{MATERIAL AND METHODS}

The accessions were collected in traditional communities of Vale do Ribeira, these being quilombos, Indigenous villages, and caiçaras communities. Accessions were also collected in peri-urban vegetable gardens where sweet potatoes are grown for subsistence and in small farms, from February to November, 2013. The Vale do Ribeira is characterized, according to Köppen's classification, as Af climate, i.e. mild winters, hot and humid summers, and without a dry season.

In total, 95 sweet potato accessions were collected in seven municipalities of Vale do Ribeira. After collection and identification, the genetic material was taken to UNESP Campus of Registro. The accession's field evaluation was carried out at the Experimental Farm of UNESP, in the municipality of Registro-SP (24'29'15'S, 4750'37'”, $19 \mathrm{~m}$ altitude), between February and August, 2014.

The experimental design adopted was randomized blocks, with three replications. The experimental plot was composed of 10 plants in a single row, considering as useful area of the plot the eight central plants. The treatments consisted of 95 accessions and two commercial cultivars as controls, Brazlândia Branca and Brazlândia Roxa, thus totaling 97 genotypes.

The seedlings containing eight internodes were transplanted into the field in spacings between rows of $1 \mathrm{~m}$ and between plants of $0.25 \mathrm{~m}$, totaling 40 thousand plants per hectare. The soil preparation, as well as the management and fertilization practices, were carried out according to the recommendations for the crop (Raij et al., 1997).

Plants were harvested five months after planting date. The characteristics evaluated were: 1) Total root production (TRP) (mass of all harvested roots in the plot and later converted to $\mathrm{kg} \mathrm{ha}^{-1}$; 2) Marketable root production (MRP) (root mass, with individual mass above $80 \mathrm{~g}$, in the plot and later converted to $\mathrm{kg} \mathrm{ha}^{-1}$ ); 3) Total dry root mass production (DRM) [ $2 \mathrm{~kg}$ of root samples were dried in an oven at $65^{\circ} \mathrm{C}$ until constant mass (\%); subsequently, the dry mass content was multiplied by the total root production]; 4) Total branch production (TBP) (obtained by cutting the branches and leaves at ground level, with subsequent weighing of the plot and converted to $\left.\mathrm{kg} \mathrm{ha}^{-1}\right) ; 5$ ) Total dry branch mass production (DBM) $[2 \mathrm{~kg}$ of shoot samples were crushed, then placed in an oven at $65^{\circ} \mathrm{C}$ until constant mass to determine the dry mass content (\%); subsequently, the dry branch mass was multiplied by the total branch production].

Statistical analyzes were performed using the computer program Genes (Cruz, 2006, 2013). Each characteristic was subjected to analysis of variance using the statistical model

$$
Y_{i j}=\mu+g_{i}+b_{j}+e_{i j}
$$

where: $Y_{i j}$ is the value observed in the $i$-th genotype of the $j$-th block $(\mathrm{j}=1$, $2,3) ; \mu$ is the general mean of the experiment; $g_{i}$ is the effect of the $i$-th genotype; $b j$ is the effect of the $j$-th block; and $e_{i j}$ is the experimental error associated with the observation $Y_{i j}$.

Analysis of direct gains with the selection was carried out for the predicted gains. Also, the selection index proposed by Mulamba \& Mock (1978) was employed according to the statistical model

$$
I_{j}=\Sigma_{n i j}
$$

wherein: $I_{j}$ is the index for the genotype $\mathrm{j}$; and $n_{i j}$ is the classification number of character i, for genotype $\mathrm{j}$ (França et al., 2016).

The index proposed by Mulamba \& Mock (1978) hierarchized the genotypes ordering according to each desired character, and subsequently, the sum of the ranks based on the multiple characters evaluated was performed, thus obtaining the classification of the genotypes by ranks.

Economic weights were used to maximize the gains obtained, making the index as balanced as possible, to find the one that predicted the greatest genotypic gain. The values and signs of the economic weights were adopted according to the selection direction, assigning greater importance to more relevant economic and agronomic 
characters, being positive when the selection is favorable and negative when the selection is against that specific character.

First, positive weights for root characters and negative weights for shoot parts were adopted, with weight 4 for total and marketable root production, 3 for dry root mass, and -1 for total root production and total dry branches mass production, to select superior accessions for root production. The negative score for shoot production was determined as this characteristic hinders the crop semi-mechanized harvesting process, thus, the identification of genotypes with good root production capacity and less shoot volume is a demand of the productive sector. In addition, there is no positive correlation between root and shoot production in the sweet potato crop (Azevedo et al., 2015). Then, positive weights were used for both characteristics, being 2 for root characters and 1 for shoot production, this time to select accessions that have dual-aptitude, i.e. productive both in shoot and in roots.

\section{RESULTS AND DISCUSSION}

All evaluated characteristics showed significant genetic variability between sweet potato accessions (Table 1), enabling gains with selection. The coefficients of variation of the analyzed variables ranged between 7.32 (TRP) and 12.17 (TBP), providing good experimental precision.

Significant genetic variances and low $\mathrm{CV}$ resulted in high magnitude broadsense heritabilities for all characters (Table 1), ranging from 0.9881 (98.81\%) to $0.9707(97.07 \%)$, demonstrating that these characteristics are highly inheritable and easy to proceed with the selection in sweet potato accessions, which opens space for relevant gains in breeding programs. In sweet potatoes, broad-sense heritability is important because the effects of dominance and epistasis are maintained by vegetative propagation (Gonçalves Neto et al., 2012).

Other authors have also identified medium to high heritabilities for sweet potato accessions. Cavalcante et al. (2009) assessed the productive and genetic potentials of nine accessions and two commercial cultivars of sweet potato and obtained high heritability, however slightly inferior to the present study in total root production $(95.39 \%)$ and total branch production (93.28\%). Carmona et al. (2015), in a genetic divergence study between sweet potato accessions, reported minor heritabilities, ranging from $59 \%$ to $85.42 \%$.

The heritability is an important parameter, as it enables the prediction of the possibility of success with the selection since it reflects the proportion of the inherited phenotypic variation, i.e. it quantifies the reliability of the phenotypic value as an indicator of the reproductive value (Rodrigues et al., 2011). Also, along with the $\mathrm{CVg} / \mathrm{CVe}$ ratio, the heritability measures the data reliability (Faluba et al., 2010).

Such experimental precision and high variability also provided high values of the ratio between the coefficients of genetic and environmental variation (CVg/CVe), the lowest being 3.32 for DRM and the highest being 5.26 for TRP (Table 1), which shows that the evaluated characters are ideal to be used in breeding programs, as they indicate that genetic causes are acting more than environmental ones. Gonçalves Neto et al. (2012) cite that $\mathrm{CVg} / \mathrm{CVe}$ greater than 1 indicates high variability and a favorable situation for selection.
Gonçalves Neto et al. (2012) evaluated the correlation between characters and estimation of population parameters in sweet potatoes, obtained $\mathrm{CVg} / \mathrm{CVe}$ above 1 in total root production (3.34), but the value was lower than in this study. Azevedo et al. (2015) studied the agronomic performance and genetic parameters in sweet potatoes and observed $\mathrm{CVg} / \mathrm{CVe}$ higher than 1 only for marketable root production (1.08). Carmona et al. (2015), in a study of genetic divergence between sweet potato accessions, reported $\mathrm{CVg} / \mathrm{CVe}$ values lower than that obtained in the present study for total and marketable production of sweet potato roots, being 1.05 and 0.93 , respectively.

Little genetically-improved species, as in the case of sweet potatoes, tend to present high genetic variability, indicating that the crop has a high potential for exploration for future breeding programs. According to Azevedo et al. (2015), the expressive genetic variability found in sweet potatoes provides a large number of genotypes to be tested and evaluated to obtain new cultivars through selection and genetic improvement, thus constituting continuous and dynamic work. Oliveira et al. (2012) report that studies on genetic variability and divergence are essential to advance new selection cycles, in addition to assisting in the identification and relationship between parents.

Table 1. Estimates of genetic parameters and direct gains with selection in characters of sweet potato accessions. Registro, UNESP, 2020.

\begin{tabular}{lccccc}
\hline Parameters & TRP $^{\mathbf{1}}$ & $\mathbf{M R P}^{\mathbf{2}}$ & $\mathbf{D R M}^{\mathbf{3}}$ & $\mathbf{T B P}^{\mathbf{4}}$ & $\mathbf{D B M}^{\mathbf{5}}$ \\
\hline$\sigma^{2}{ }_{\mathrm{g}}$ & $76169674^{* *}$ & $81055664^{* *}$ & $4831893^{* *}$ & $253859710^{* *}$ & $5179621^{* *}$ \\
$\mathrm{~h}^{2}$ & 0.9881 & 0.9858 & 0.9707 & 0.9769 & 0.9772 \\
$\mathrm{CVg} \%$ & 38.51 & 42.16 & 33.41 & 45.73 & 42.85 \\
$\mathrm{CVg} / \mathrm{CVe}$ & 5.26 & 4.81 & 3.32 & 3.75 & 3.78 \\
$\mathrm{GS}$ & 22.0 & 22.4 & 4.3 & 49.3 & 6.6 \\
$\mathrm{GS} \%$ & 97.37 & 105.21 & 66.48 & 141.64 & 125.55 \\
Average & 22662.09 & 21351.31 & 6577.91 & 34838.61 & 5310.91 \\
$\mathrm{CV}(\%)$ & 7.32 & 8.75 & 10.05 & 12.17 & 11.32
\end{tabular}

$\sigma_{\mathrm{g}}^{2}=$ genetic variance; $\mathrm{h}^{2}=$ heritability; $\mathrm{CV}_{\mathrm{g}}=$ genotypic coefficient of variation; $\mathrm{CV}_{\mathrm{g}}$ $\mathrm{CV}_{\mathrm{e}}=$ relative coefficient of variation between $\mathrm{CV}_{\mathrm{g}}$ and $\mathrm{CV}_{\mathrm{e}}$ (experimental coefficient of variation); $\mathrm{GS}=$ selection gain; $\mathrm{GS} \%=$ selection gain (percentage), given by $\mathrm{SG} \%=\mathrm{SG} /$ (mean gain)*100). ${ }^{1}$ Total root production $\left(\mathrm{t} \mathrm{ha}^{-1}\right){ }^{2}$ Marketable root production $\left(\mathrm{t} \mathrm{ha}^{-1}\right) ;{ }^{3}$ Total dry root mass production $\left(\mathrm{t} \mathrm{ha}^{-1}\right) ;{ }^{4}$ Total branch production $\left(\mathrm{t} \mathrm{ha}^{-1}\right) ;{ }^{5}$ Total dry branch mass production $\left(\mathrm{t} \mathrm{ha}^{-1}\right) ; * *$ significant at $1 \%$. 
The estimates of selection gains exceeded $100 \%$ for marketable root production (105.21\%), total branch production (141.64\%), and total dry branch mass production (125.55\%)
(Table 1). In addition to the other characters showing positive selection gains, the high expectation of genetic gains corroborates with the other parameters analyzed, providing high-

Table 2. Estimated gains through the selection for the characters TRP, MRP, DRM, TBP, and DBM, and classification of the five best sweet potato accessions for root production submitted to the analysis of selection gains according to the index proposed by Mulamba \& Mock (1978) and the result of the two commercial cultivars. Registro, UNESP, 2020.

\begin{tabular}{|c|c|c|c|c|c|c|}
\hline \multicolumn{2}{|c|}{ Estimated gains } & TRP $^{1}$ & MRP $^{2}$ & DRM $^{3}$ & $\mathrm{TBP}^{4}$ & DBM $^{5}$ \\
\hline \multicolumn{2}{|l|}{$\mathrm{DS}$} & 15.10 & 15.20 & 2.40 & -1.00 & -0.40 \\
\hline \multicolumn{2}{|l|}{ GS } & 14.90 & 15.00 & 2.40 & -1.00 & -0.40 \\
\hline \multicolumn{2}{|c|}{$\mathrm{GS} \%$} & 65.91 & 70.31 & 36.79 & -2.95 & -7.61 \\
\hline \multicolumn{2}{|c|}{ Rank } & $\begin{array}{c}\text { Selected } \\
\text { accessions }\end{array}$ & & & & \\
\hline $1^{\mathrm{o}}$ & VR13-52 & 33.7 & 31.7 & 8.8 & 43.8 & 5.0 \\
\hline $2^{\circ}$ & VR13-31 & 27.9 & 26.7 & 9.5 & 48.8 & 7.9 \\
\hline $3^{\circ}$ & VR13-48 & 33.5 & 32.8 & 10.2 & 26.5 & 4.2 \\
\hline $4^{\circ}$ & VR13-61 & 47.6 & 47.2 & 8.9 & 17.5 & 3.2 \\
\hline $5^{\circ}$ & VR13-44 & 46.0 & 44.4 & 7.6 & 32.1 & 4.0 \\
\hline Ave & age & 37.7 & 36.5 & 9.0 & 33.7 & 4.8 \\
\hline $\mathrm{Bra}$ & ândia Branca & 32.4 & 32.1 & 6.8 & 37.2 & 8.0 \\
\hline $\mathrm{Bra}$ & ândia Roxa & 27.6 & 27.1 & 6.8 & 51.5 & 9.3 \\
\hline
\end{tabular}

$\mathrm{DS}=$ Selection differential $\left(\mathrm{t} \mathrm{ha}^{-1}\right) ; \mathrm{GS}=$ selection gain $\left(\mathrm{t} \mathrm{ha} \mathrm{a}^{-1}\right) ; \mathrm{GS} \%=$ selection gain $(\%)$, given by $\mathrm{SG} \%=\mathrm{SG} /\left(\right.$ mean gain)*100); ${ }^{1}$ Total root production $\left(\mathrm{t} \mathrm{ha}^{-1}\right) ;{ }^{2}$ Marketable root production $\left(\mathrm{t} \mathrm{ha}^{-1}\right) ;{ }^{3}$ Total dry root mass production $\left(\mathrm{t} \mathrm{ha}^{-1}\right) ;{ }^{4}$ Total branch production $\left(\mathrm{t} \mathrm{ha}^{-1}\right)$; ${ }^{5}$ Total dry branch mass production $\left(\mathrm{t} \mathrm{ha}{ }^{-1}\right)$.

Table 3. Estimated gains through the selection for the characters TRP, MRP, DRM, TBP, and DBM, and classification of the five best sweet potato accessions for dual-aptitude submitted to the analysis of selection gains according to the index proposed by Mulamba \& Mock (1978) and the result of the two commercial cultivars. Registro, UNESP, 2020.

\begin{tabular}{|c|c|c|c|c|c|c|}
\hline \multicolumn{2}{|c|}{ Estimated gains } & TRP ${ }^{1}$ & MRP $^{2}$ & DRM $^{3}$ & TBP $^{4}$ & DBM $^{5}$ \\
\hline \multicolumn{2}{|l|}{ DS } & 13.00 & 12.80 & 3.30 & 2.30 & 3.10 \\
\hline \multicolumn{2}{|l|}{ GS } & 12.80 & 12.60 & 3.20 & 22.80 & 3.00 \\
\hline \multicolumn{2}{|c|}{ GS $\%$} & 56.90 & 59.16 & 49.92 & 65.53 & 58.18 \\
\hline \multicolumn{2}{|c|}{ Rank } & $\begin{array}{c}\text { Selected } \\
\text { accessions }\end{array}$ & & & & \\
\hline $1^{\circ}$ & VR13-22 & 35.3 & 33.8 & 10.5 & 8.8 & 12.3 \\
\hline $2^{\circ}$ & VR13-11 & 44.6 & 43.2 & 12.4 & 65.3 & 7.1 \\
\hline $3^{\circ}$ & VR13-41 & 35.4 & 33.9 & 8.9 & 43.1 & 8.6 \\
\hline $4^{\circ}$ & VR13-31 & 27.9 & 26.7 & 9.5 & 48.8 & 7.9 \\
\hline $5^{\circ}$ & VR13-84 & 35.2 & 33.1 & 8.3 & 45.4 & 6.3 \\
\hline \multicolumn{2}{|c|}{ Average } & 35.7 & 34.1 & 9.9 & 58.2 & 8.4 \\
\hline \multicolumn{2}{|c|}{ Brazlândia Branca } & 32.4 & 32.1 & 6.8 & 37.2 & 8.0 \\
\hline \multicolumn{2}{|c|}{ Brazlândia Roxa } & 27.6 & 27.1 & 6.8 & 5.1 & 9.3 \\
\hline
\end{tabular}

$\mathrm{DS}=$ Selection differential $\left(\mathrm{t} \mathrm{ha}^{-1}\right) ; \mathrm{GS}=$ selection gain $\left(\mathrm{t} \mathrm{ha}{ }^{-1}\right) ; \mathrm{GS} \%=$ selection gain $(\%)$, given by $\mathrm{SG} \%=\mathrm{SG} /($ mean gain) $* 100)$; ${ }^{1}$ Total root production $\left(\mathrm{t} \mathrm{ha}^{-1}\right) ;{ }^{2}$ Marketable root production $\left(\mathrm{t} \mathrm{ha}^{-1}\right) ;{ }^{3}$ Total dry root mass production $\left(\mathrm{t} \mathrm{ha}^{-1}\right) ;{ }^{4}$ Total branch production $\left(\mathrm{t} \mathrm{ha}^{-1}\right)$; ${ }^{5}$ Total dry branch mass production $\left(\mathrm{t} \mathrm{ha}^{-1}\right)$.

magnitude selection gains that would even double the marketable root production.

To be launched, a cultivar must have a series of desirable attributes simultaneously, which suggests that the selection of a single characteristic does not match the reality of modern agriculture. Thus, multivariate selection using selection indexes is an adequate tool to achieve these objectives, assuming that the adoption of selection indexes tends to provide balanced gains for all studied characters, which facilitates the data systematization, interpretation, and selection.

The Mulamba \& Mock index enabled the identification of genetic gains favorable to the direction of selection for all studied characters (Tables 2 and 3). When the selection aimed only at root production gains, these were positive, and negative for branches. Growers who only aim at root production are often not interested in high-branch producing genotypes. When the selection was for double-use, looking for materials that present good production both in roots and in shoot parts, this being destined for animal feed, the index also provided gains in all characteristics, demonstrating the high efficiency of selection indexes for selection of sweet potato accessions.

The efficiency of the index proposed by Mulamba \& Mock has been reported in several crops, such as potato (Terres et al., 2015), acid passion fruit (Rosado et al., 2012), yellow passion fruit (Krause et al., 2012), papaya (Vivas et al., 2012), and coffee (Carias et al., 2016), which makes its use reliable by providing the selection of genotypes with more balanced agronomic characteristics, meeting the demand of both farmers and consumers.

\section{Selection of sweet potato accessions for root production}

Considering the selection of accessions only for root production, with no interest for gains for shoot production, there were positive gains in total root production, marketable root production, and total dry root mass production. Total branches production and total dry branch mass production 
showed negative gains, which is the objective at the moment. Marketable root production was the variable with the highest selection gain $(70.31 \%)$, followed by total root production with $65.91 \%$ (Table 2).

The selection differential consists of the difference between the average of the original population and the average of the improved population, the gain obtained is directly related to this differential. Among genotypes with aptitude only for root production, the selection differential ranged from 15.2 to -1.0 (Table 2), with negative results for total branch production and total dry branch mass production, since $a$ priori, it aimed at the lowest possible production of part of the access area.

The indices are used for genotype selection based on multiple characters. However, when necessary, there is the possibility of obtaining negative genetic gains in an individual character that is not currently desired (Krause et al., 2012). Therefore, aiming at the negative gain in the shoot part, among the 97 accessions, the five most productive in root characters were selected: VR1352, VR13-31, VR13-48, VR13-61, and VR13-44, presented in Table 2.

The two commercial cultivars Brazlândia Branca and Brazlândia Roxa were not selected according to the selection index adopted. As for root production, the cultivar Brazlândia Roxa was inferior to the accessions selected in two of the targeted characteristics for the moment, TRP and DRM, being superior to the accession VR13-31 only in MRP. The cultivar Brazlândia Branca was slightly superior to VR13-31 in TRP and MRP. Even though presenting results similar to some of the selected accessions, both commercial cultivars demonstrate good shoot production and considering that the selection was carried out, in this context, only for root production with the minimum of shoot part possible, they were not selected. Also, the average of the selected accessions was superior to the commercial cultivars in all root characters. In view of this, having demonstrated the commercial potential of the accessions selected for root production, they can be recommended to compose sweet potato breeding programs aiming at tests of value for cultivation, to ultimately obtain new commercial cultivars.

Accessions VR13-61 and VR1344 were significantly superior to the commercial cultivars studied, with almost $20 \mathrm{t} \mathrm{ha}^{-1}$ difference between the cultivar Brazlândia Roxa and access VR13-61.

Despite the high potential sweet potato production, the Brazilian yield is around $12 \mathrm{t} \mathrm{ha}^{-1}$, indicating the superiority of the population selected in the present study as the access with the lowest MRP reached $26.7 \mathrm{t} \mathrm{ha}^{-1}$, i.e. 14 $\mathrm{t}^{-1} \mathrm{a}^{-1}$ more than the Brazilian average. The access with the best performance obtained $47.2 \mathrm{t} \mathrm{ha}^{-1}$, representing $35 \mathrm{t}$ $\mathrm{ha}^{-1}$ more than the national average.

The average of the selected population (Table 2) was higher than the general average (Table 1) for the three root characters evaluated, with gains of $14.9 \mathrm{t} \mathrm{ha}^{-1}$ in TRP, $15.0 \mathrm{t} \mathrm{ha}^{-1}$ in MRP, and 2,4 $\mathrm{tha}^{-1}$ in DRM proving the positive gains.

Among the five selected accessions, the total root production ranged from 27.9 to $47.6 \mathrm{t} \mathrm{ha}^{-1}$, whereas the accessions with the lowest and highest results were, respectively, VR13-31 and VR13-61 (Table 2). The same occurred for marketable root production. Andrade Júnior et al. (2012) evaluated 12 sweet potato accessions and reported inferior total root production, with only one accession having a higher yield than those selected in the present study. Silva et al. (2015) assessed the performance of sweet potato cultivars and found inferior results in the two-year study, with an average of $21.2 \mathrm{t} \mathrm{ha}^{-1}$ in 2012 and 23.6 $\mathrm{t} \mathrm{ha}^{-1}$ in 2013.

As for MRP, Andrade Júnior et al. (2012) demonstrated lower average results, ranging from 8.0 to $29.5 \mathrm{t}$ $\mathrm{ha}^{-1}$, and only one of the accessions outperformed those in this study. For DRM, the authors found considerably lower results, ranging from 1.2 to 3.5 $\mathrm{t} \mathrm{ha}^{-1}$. Gonçalves Neto et al. (2012) evaluated 39 sweet potato genotypes and reported an average of $8.9 \mathrm{tha}^{-1}$ for dry root mass.

For total branches production (Table
2 ), the best performances were the accessions VR13-31 with $48.8 \mathrm{tha}^{-1}$ and VR13-52 with $43.8 \mathrm{t} \mathrm{ha}^{-1}$. For total dry branch mass production, the accession that presented the best result was VR1331 with $7.9 \mathrm{t} \mathrm{ha}^{-1}$.

Comparing each characteristic with their respective averages among the selected accessions, VR13-61 and VR13-44 were the only ones that obtained values higher than the total average concerning the total and commercial root production. However, in DRM, TBP, and DBM, VR13-61 and VR13-44 showed averages below the general average. As in this first selection the objective was to obtain as little shoot part as possible, the two accessions are promising, even though both show results below the average for dry root mass.

For root production (total, marketable, and total dry mass), VR1361 is the most promising accession, as it obtained better results in total and marketable root production, and placing third for total dry root mass, in addition to being the selected accession that presented lower results in shoot characters.

\section{Selection of sweet potato accessions for dual-aptitude}

The selection for dual-aptitude aimed to identify genotypes with good performance for both root and shoot production. The shoot production is destined for animal feed. There were positive gains in all the evaluated characters (Table 3). Total branch production presented the highest gain, $65.53 \%$, followed by marketable root production with $59.16 \%$. The lowest gain was observed for dry root mass, with $49.92 \%$ (Table 3 ).

About root production selection, the five best among the 97 accessions were selected for dual-aptitude, namely: VR13-22, VR13-11, VR13-41, VR1331, and VR13-84.

No negative results were verified for the selection differentials (Table 3 ), which was desirable as accessions were selected for dual-aptitude seeking positive gains in all the evaluated characters, both in root and shoot production, differently than what was 
previously presented when promising accessions were sought only for root production (Table 2).

Once again, VR13-96 and VR1397, the commercial cultivars were not selected among the accessions with dual-aptitude. When compared with those selected, VR13-97 performed lower in all root production characters, but higher in shoot production (TBP) than three accessions, VR13-84, VR1331, and VR13-41, however, with results lower than the average of the selected accessions.

The accession VR13-31 was the only one selected for both root production (Table 2) and dual-aptitude (Table 3). Among the selected accessions, VR1311 with $44.6 \mathrm{t} \mathrm{ha}^{-1}$ was the best for total root production, followed by VR13-41 with $35.4 \mathrm{t} \mathrm{ha}^{-1}$ (Table 3 ). The same was observed for marketable root production, whereas VR13-11 and VR13-41 showed better performance with 43.2 and $33.9 \mathrm{t}$ ha $^{-1}$, respectively, with VR13-31 being the accession with the lowest average for MRP. The accession VR13-11 also had a higher average for dry root mass, with $12.4 \mathrm{t} \mathrm{ha}^{-1}$.

As for shoot production, VR1322 averaged higher in total branch production and total dry branch mass production, with 88.2 and $12.3 \mathrm{t} \mathrm{ha}^{-1}$, respectively. Andrade Júnior et al. (2014), in a study with sweet potato branches, reported lower dry mass production, with an average of $6.4 \mathrm{tha}^{-1}$.

Considering the average of each accession for each characteristic, and comparing them with the general average, VR13-11 was the only superior in total and marketable root production, raising the general average for demonstrating considerable superiority to the other accessions in these characters. For dry root mass and total branch production, VR13-22 and VR13-11 were superior to the other accessions, presenting average higher than the general average. VR13-22 was also higher than the general average in total dry branch mass production, together with VR13-41.

The studied population showed high genetic variability, providing considerable selection gains. The selected accessions showed expressive results for yield, which indicates good potential as parents to be adopted in breeding programs.

In general, the selected accessions were superior to commercial cultivars, being recommended for tests of value for cultivation and use for possible cultivars release. Among the selected accessions, VR13-61 is the most recommended for root production, because in addition to showing superiority in root characteristics, it was the least productive in shoot parts. As for the selection for dual-aptitude, VR13-11 and VR13-22 are promising.

\section{ACKNOWLEDGMENTS}

This research was supported by grant 2012/08763-0, FAPESP (São Paulo Research Foundation), and by CAPES (Coordination for the Improvement of Higher Education Personnel) through granting of a master's scholarship.

\section{REFERENCES}

ANDRADE JÚNIOR, VC; PEREIRA, RC; DORNAS, MFS; RIBEIRO, KG; VALADARES, NR; SANTOS, AA; CASTRO, BMC. 2014. Produção de silagem; composição bromatológica e capacidade fermentativa de ramas de batata-doce emurchecidas. Horticultura Brasileira 32: 91-97.

ANDRADE JÚNIOR, VC; VIANA, DJS; PINTO, NAVD; RIBEIRO, KG; PEREIRA RC; NEIVA, IP; AZEVEDO, AM; ANDRADE, PCR. 2012. Características produtivas e qualitativas de ramas e raízes de batata-doce. Horticultura Brasileira 30: 584-589.

AZEVEDO, AM; ANDRADE JÚNIOR, VC; FERNANDES, JSC; PEDROSA, CE; OLIVEIRA, CM. 2015. Desempenho agronômico e parâmetros genéticos em genótipos de batata-doce. Horticultura Brasileira 33: 84-90.

CARIAS, CMOM; GRAVINA, GA; FERRÃO, MAG; FONSECA, AFA; FERRÃO, RG; VIVAS M; VIANA AP. 2016. Predição de ganhos genéticos via modelos mistos em progênies de café conilon. Coffee Science 11: 39-45.

CARMONA, PAO; PEIXOTO, JR; AMARO, GB; MENDONÇA, MA. 2015. Divergência genética entre acessos de batata-doce utilizando descritores morfoagronômicos das raízes. Horticultura Brasileira 33: 241-250.

CAVALCANTE, M; FERREIRA, PV; PAIXÃO, SL; COSTA, JC; PEREIRA, RG; MADALENA, JAS. 2009. Potenciais produtivo e genético de acessos de batata-doce. Acta Scientiarum Agronomy 31: 421-426.

CRUZ, CD. 2006. Programa genes: biometria. Editora UFV; Viçosa.

CRUZ, CD. 2013. GENES - a software package for analysis in experimental statistics and quantitative genetics. Acta Scientiarum Agronomy 35: 271-276.

CRUZ, CD; REGAZZI, AJ; CARNEIRO, PCS. 2004. Modelos biométricos aplicados ao melhoramento genético. 3 ed. Viçosa: Editora UFV. 480p.

FALUBA, JS; MIRANDA, GV; LIMA, RO; SOUZA LV; DEBEM, EA; OLIVEIRA, AMC. 2010. Potencial genético da população de milho UFV 7 para melhoramento em Minas Genais. Ciência Rural 40: 1250-1256.

FRANÇA, AED; PARRELLA, RAC; SOUZA, VF; BASTOS, GQ; NUNES, JAR; SCHAFFERT, RE. 2016. Seleção simultânea em progênies de sorgo-sacarino por meio de índices de seleção. Pesquisa Agropecuária Brasileira 51: 1737-1743.

FREITAS JÚNIOR, SP, AMARAL JÚNIOR, AT, RANGEL, RM, VIANA, AP. 2009. Genetic gain prediction on UNB-2U popcorn population under recurrent selection by using different selection indexes. Semina: Ciências Agrárias 30: 803-814.

GONÇALVES NETO, AC; MALUF, WR; GOMES, LAA; MACIEL, GM; FERREIRA, RPD; CARVALHO RC. 2012. Correlação entre caracteres e estimação de parâmetros populacionais para batata-doce. Horticultura Brasileira 30: 713-719.

KRAUSE, W; SOUZA, RS; NEVES, LG; CARVALHO, MLS; VIANA, AP; FALEIRO, FG. 2012. Ganho de seleção no melhoramento genético intrapopulacional do maracujazeiro-amarelo. Pesquisa Agropecuária Brasileira 47: 51-57.

MARCHESE, A; MALUF, WR; GONÇALVES NETO, AC; GONÇALVES, RJS; GOMES LAA. 2010. Seleção de acessos de batatadoce resistentes a Meloidogyne incognita raça 1. Pesquisa Agropecuária Brasileira 45: 997-1004.

MASSAROTO, JA; MALUF, WR; GOMES, LAA; FRANCO, HD; GASPARINO, CF. 2014. Desempenho de acessos de batata-doce. Ambiência 10: 73-81.

MONTEIRO, AB; MASSAROTO, JA; GASPARINO, CF; SILVA, RR; GOMES LAA; MALUF, WR; SANTOS FILHO, JC. 2007. Silagens de cultivares e acessos de batata doce para alimentação animal visando sustentabilidade da produção agrícola familiar. Revista Brasileira de Agroecologia 2: 978981.

MULAMBA, NN; MOCK, JJ. 1978. Improvement of yield potential of the Eto Blanco maize (Zea mays L.) population by breeding for plant traits. Egypt Journal of Genetics and Cytology 7: 40-51.

OLIVEIRA, NP; OLIVEIRA, MSP; MOURA, EF. 2012. Variabilidade e divergência genética entre genótipos de Tucumanzeiro-do-Pará (Astrocaryum vulgare Mart.) promissores para a produção de frutos por marcadores 
RAPD. Revista Brasileira de Fruticultura 34: 216-226.

RAIJ, BV; CANTARELLA, H.; QUAGGIO, JA; FURLANI, AMC. 1997. Recomendações de adubação e calagem para o estado de São Paulo, 2 ed. Campinas: Instituto Agronômico \& Fundação IAC. 285p. (Boletim Técnico, $100)$.

RODRIGUES, F; PINHO, RGV; ALBUQUERQUE, CJB; PINHO, EVRV. 2011. Index of selection and estimation of genetic and phenotypical parameters for traits related with the production of vegetable corn. Ciência e Tecnologia 35: 278-286.

ROSADO, LDS; SANTOS, CEM.; BRUCKNER, CH; NUNES, ES; CRUZ, CD. 2012. Simultaneous selection in progenies of yellow passion fruit using selection indices. Revista Ceres 59: 95-101.

SILVA, GO; SUINAGA, FA; PONIJALEKI, R; AMARO, GB. 2015. Desempenho de cultivares de batata-doce para caracteres relacionados com o rendimento de raiz. Revista Ceres 62: 379-383.

TERRES, LR; LENZ, E; CASTRO, CM; PEREIRA, AS. 2015. Estimativas de ganhos genéticos por diferentes índices de seleção em três populações híbridas de batata. Horticultura brasileira 33: 305-310.

VIVAS, M; SILVEIRA, SF; PEREIRA, MG. 2012. Prediction of genetic gain from selection indices for disease resistance in papaya hybrids. Revista Ceres 59: 781-786. 